\title{
Accumulation of Aluminium by Anabaena cylindrica into Polyphosphate Granules and Cell Walls: an X-ray Energy-dispersive Microanalysis Study
}

\author{
By ANNETTE PETTERSSON, ${ }^{*}$ LJERKA KUNST, ${ }^{2}$ BIRGITTA \\ BERGMAN ${ }^{1}$ AND GODFRIED M. ROOMANS ${ }^{2}$
}

${ }^{1}$ Institute of Physiological Botany, University of Uppsala, Box 540, S-751 21 Uppsala, Sweden

${ }^{2}$ Department of Ultrastructure Research, University of Stockholm, S-106 91 Stockholm, Sweden

(Received 7 February 1985; revised 23 May 1985)

\begin{abstract}
X-ray microanalysis of thin cryosections of the cyanobacterium Anabaena cylindrica showed that aluminium was rapidly taken up and accumulated into polyphosphate granules. In addition, aluminium was found in the cell walls but could not be detected in the cytoplasm. The concentration of phosphorus in the medium affected the accumulation pattern; more aluminium was bound in the polyphosphate granules and in the cell walls after growth in phosphorus-rich medium. The accumulation of aluminium in these structures may function as a detoxification mechanism. Treatment with aluminium for $24 \mathrm{~h}$ did not cause any significant changes in the elemental composition of polyphosphate granules or cell walls.
\end{abstract}

\section{INTRODUCTION}

As a consequence of acidification, elevated concentrations of solubilized aluminium in both soils and waters have become a serious problem in industrial areas. Toxic effects of aluminium on various organisms are well known (for reviews see Foy et al., 1978; Haug, 1984), but the mechanisms of its uptake, distribution in the cell and metabolic effects have not yet been evaluated.

We have studied the physiological, biochemical and structural effects of aluminium on cyanobacteria, as these organisms may be important primary producers in both waters and soils now affected by acidification. In a previous paper we reported on the inhibitory effects of aluminium on growth, photosynthesis and nitrogen fixation of Anabaena cylindrica (Pettersson et al., 1985).

In the present communication the accumulation of aluminium in $A$. cylindrica was investigated by energy-dispersive $\mathrm{X}$-ray microanalysis, in order to determine whether aluminium was taken up into the cyanobacterial cells as indicated in our previous study (Pettersson et al., 1985) or was merely affecting the cells from the outside.

\section{METHODS}

Organism and culture conditions. Anabaena cylindrica strain 1403/2a (Culture Centre of Algae and Protozoa, Cambridge, UK), was grown axenically in 0.51 growth medium as previously described (Pettersson et al., 1985). The culture was harvested after $8 \mathrm{~d}$ of growth (exponential growth phase), washed with sterile water and resuspended in autoclaved medium buffered to $\mathrm{pH} 6 \cdot 0$ with $10 \mathrm{mM}$-MES to a density of $4.2 \mu \mathrm{g}$ chlorophyll $a \mathrm{ml}^{-1}$. Two concentrations of $\mathrm{K}_{2} \mathrm{HPO}_{4}$ were used: $180 \mu \mathrm{M}$ (high phosphate), the normal concentration of the growth medium, or $35 \mu \mathrm{M}$ (low phosphate), comparable to concentrations of phosphate naturally occurring. A volume of $10 \mathrm{ml}$ cyanobacterial suspension was added to $120 \mathrm{ml}$ Erlenmeyer flasks. Aluminium was supplied as $\mathrm{AlCl}_{3} \cdot 6 \mathrm{H}_{2} \mathrm{O}$ from freshly prepared stock solutions to a concentration of 0,19 or $190 \mu \mathrm{M}$. The lower aluminium concentration is comparable to that occurring in acid lakes; the high aluminium supplement was used to obtain a more rapid response by the organism. The flasks were placed in continuous light $\left(60 \mu \mathrm{mol}\right.$ photons $\left.\mathrm{m}^{-2} \mathrm{~s}^{-1}\right)$ at $25^{\circ} \mathrm{C}$ and shaken gently. The incubation lasted 4 or $24 \mathrm{~h}$. 
Preparation for X-ray microanalysis. The cyanobacteria were centrifuged and resuspended in a small volume of $20 \%(\mathrm{w} / \mathrm{v})$ gelatin, liquefied in distilled water (Roomans, $1980 \mathrm{a}$ ). Small pieces of the solidified gelatin containing the cyanobacterial cells were placed onto silver pins and frozen in Freon 13 subcooled by liquid nitrogen as described by Barnard (1982). Thin (about $100 \mathrm{~nm}$ ) cryosections were cut on an LKB Ultrotome III equipped with an LKB CryoKit at a specimen temperature of $-110^{\circ} \mathrm{C}$ and a knife temperature of $-100{ }^{\circ} \mathrm{C}$. The sections were cut on a dry knife and collected with a hair probe onto copper grids covered with Formvar film (Roomans \& Sevéus, 1976; Roomans et al., 1982). The sections were dried in the cryochamber at $-100^{\circ} \mathrm{C}$ for several hours and slowly brought to room temperature. In a dry box, the sections were covered with a second Formvar film, which subsequently was coated with a thin conductive carbon layer. The grids were then immediately transferred to the electron microscope for analysis.

$X$-ray microanalysis. Energy-dispersive X-ray microanalysis was done with a Kevex 7000 spectrometer system in combination with a JEOL 100C electron microscope with an ASID-4B scanning attachment. A carbon specimen holder (Liljesvan \& Roomans, 1976) was used. The sections were viewed in the scanning transmission mode and analysed at $100 \mathrm{kV}$ with a stationary spot for $120 \mathrm{~s}$.

Quantitative analysis. This was done according to the principle outlined by Hall (1971). The relative peak intensity for element $x\left(R_{x}\right)$ was calculated from

$$
R_{x}=P_{x} /\left(W-W_{e}\right)
$$

where $P_{x}$ is the characteristic intensity of element $x$, determined after frequency filter background removal, $W$ is the total background in an appropriate peak-free region of the spectrum, chosen between 4 and $6 \mathrm{keV}$, and $W_{e}$ is the extraneous background in the same region of the spectrum (Gupta \& Hall, 1979; Roomans \& Kuypers, 1980). A standard was used consisting of a matrix of $20 \%$ gelatin and $5 \%$ glycerol containing mineral salts in known concentrations (Roomans \& Sevéus, 1977). This standard was frozen, sectioned and analysed in the same way as the specimen. The relative peak intensities in the specimen and standard were compared as described previously (Roomans, 1980b). For those elements not present in the standard, sensitivity factors were determined (Russ, 1974; Roomans, 1980 b) that allowed the calculation of element concentrations from measured intensity ratios. The sensitivity factors were calculated from the analysis of dried microdroplets of binary salts, obtained by spraying a salt solution onto a film-covered grid (Morgan et al., 1975).

\section{RESULTS}

The subcellular areas analysed were the outer margin of the cells (cell wall), the cytoplasm and the polyphosphate granules. Polyphosphate granules were frequently observed in both controls and aluminium-treated cells, and after incubation in either high or low phosphate medium. When the probe was placed in the cytoplasm, aluminium could not be detected in any of the treated cells regardless of the phosphate concentration used. In contrast, analysis of cell walls and polyphosphate granules of cells treated with $190 \mu \mathrm{M}$-aluminium and high phosphate showed elevated concentrations of aluminium after $4 \mathrm{~h}$ (Table 1). Incubation under the same conditions for $24 \mathrm{~h}$ resulted in further accumulation of aluminium in the cell walls but not in the polyphosphate granules (Table 1). Cells incubated in low phosphate medium with $190 \mu \mathrm{M}$ aluminium for $4 \mathrm{~h}$ accumulated less aluminium into the cell wall or the polyphosphate granules

\section{Table 1. Aluminium concentrations in cell wall and polyphosphate granules of Anabaena cylindrica}

High and low phosphate represents 180 and $35 \mu \mathrm{M}-\mathrm{K}_{2} \mathrm{HPO}_{4}$ in the medium, respectively. The aluminium concentrations are expressed as $\mathrm{mmol}(\mathrm{kg} \mathrm{dry} \text { wt cells })^{-1}$. The values given are the mean of 10 measurements $\pm \mathrm{SE}$.

\section{Incubation}

Control, high phosphate

$190 \mu \mathrm{M}-\mathrm{Al}, 4 \mathrm{~h}$, high phosphate

$190 \mu \mathrm{M}-\mathrm{Al}, 24 \mathrm{~h}$, high phosphate

$190 \mu \mathrm{M}-\mathrm{Al}, 4 \mathrm{~h}$, low phosphate

$190 \mu \mathrm{M}-\mathrm{Al}, 24 \mathrm{~h}$, low phosphate

$19 \mu \mathrm{M}-\mathrm{Al}, 4 \mathrm{~h}$, low phosphate

$19 \mu \mathrm{M}-\mathrm{Al}, 24 \mathrm{~h}$, low phosphate
Cell wall

$90 \pm 24$
$539 \pm 88^{*}$
$1588 \pm 475^{*}$
$178 \pm 368$
Lysis
$19 \pm 4$
$16 \pm 4$

Polyphosphate granules

$$
\begin{gathered}
29 \pm 5 \\
856 \pm 83^{*} \\
722 \pm 237^{*} \\
372 \pm 251 \\
\text { Lysis } \\
15 \pm 5 \\
47 \pm 4
\end{gathered}
$$

* Significantly different from control $(P<0 \cdot 01)$. 
Table 2. Elemental composition of cell wall and polyphosphate granules of Anabaena cylindrica after treatment with aluminium

The cells were grown for $24 \mathrm{~h}$ with $190 \mu \mathrm{M}$-aluminium and high phosphate $(180 \mu \mathrm{M})$ in the medium. The values are given in mmol $(\mathrm{kg} d r y \text { w } 1 \text { cells })^{-1}$ and are the mean of 10 measurements \pm SE.

$\begin{array}{ccc}\text { Element } & \text { Cell wall } & \begin{array}{c}\text { Polyphosphate } \\ \text { granules }\end{array} \\ \mathrm{Na} & 283 \pm 57 & 406 \pm 36 \\ \mathrm{Mg} & 31 \pm 13 & 325 \pm 82^{*} \\ \mathrm{Al} & 1588 \pm 475 & 722 \pm 238 \\ \mathrm{P} & 133 \pm 51 & 1222 \pm 192^{*} \\ \mathrm{~S} & 818 \pm 28 & 1350 \pm 122^{*} \\ \mathrm{Cl} & 420 \pm 24 & 771 \pm 53^{*} \\ \mathrm{~K} & 47 \pm 8 & 164 \pm 42 \\ \mathrm{Ca} & 47 \pm 8 & 65 \pm 15 \\ \mathrm{Fe} & 91 \pm 15 & 284 \pm 162\end{array}$

* Significantly higher $(P<0 \cdot 01)$ than in cell walls.

than those incubated in high phosphate medium (Table 1). Prolonged treatment with $190 \mu \mathrm{M}$ aluminium in low phosphate medium caused lysis of cells. When cells were treated with $19 \mu \mathrm{M}$ aluminium in low phosphate medium there was no detectable accumulation of aluminium in either the cell wall or the polyphosphate granules. In fact, under these conditions the aluminium concentration was even lower than that observed in the controls in the presence of high phosphate and in the absence of added aluminium.

Table 2 shows the elemental composition of cell walls and polyphosphate granules of aluminium-treated cells. Apart from the presence of aluminium, there was no significant change in the composition of either structure compared to non-treated cells. Magnesium, phosphorus, sulphur and chlorine were found in significantly higher concentrations in the polyphosphate granules than in the cell wall. The concentration of iron was also somewhat higher in the granules, but the variations were considerable.

\section{DISCUSSION}

The purpose of the study was first to investigate whether aluminium is taken up into the cell or merely adsorbed externally and secondly to determine its subcellular localization.

The results presented here provide evidence for the rapid uptake of aluminium into $A$. cylindrica and the accumulation of aluminium into the polyphosphate granules in the presence of high concentrations of phosphate. However, part of the aluminium is adsorbed to negative groups in the cell wall. At high phosphate concentrations an increased phosphate content in the cell wall could be expected and this may explain the increased levels of aluminium found in the cell wall under these conditions.

Compartmentalization of heavy metals into cell walls and polyphosphate granules has been documented both in a cyanobacterium (Jensen et al., 1982) and in marine algae (Pedersén et al., 1981). The sequestering of heavy metals into special subcellular compartments was suggested to function as a detoxification mechanism. This could also be true for aluminium, particularly in phosphate-rich medium, since under those conditions more aluminium was bound in cell walls and polyphosphate granules than when the cells were incubated in low phosphate medium (Table 1). This could be due either to an increased capacity for aluminium-binding by the cellular components or to an increased uptake rate.

The accumulation of aluminium into polyphosphate granules could also reflect a more general mode of sequestering cations in cyanobacteria. Besides functioning as phosphorus storage and as a source of energy (Kulaev \& Vagabov, 1983), the polyphosphate granules may act as a storage site for monovalent and divalent cations such as $\mathrm{K}^{+}, \mathrm{Mg}^{2+}$ and $\mathrm{Ca}^{2+}$ (Jensen et al., 1982). However, there does not seem to be any competition for their binding since we did not 
observe any loss or changes in the concentrations of these ions in cells treated with aluminium compared with non-treated cells.

The aluminium localized in the polyphosphate granules may influence the generation of phosphate and energy, disturb the translocation of other ions and could also be released and become toxic as the polyphosphate granules are metabolized.

The excellent technical assistance of Mrs Eva Björkner is gratefully acknowledged.

L. K. was on leave from the Ruder Bósković Institute, Zagreb, Yugoslavia.

This study was supported by the National Swedish Board of Environment Protection.

\section{REFERENCES}

Barnard, T. I. (1982). Thin freeze-dried cryosections and biological X-ray microanalysis. Journal of Microscopy 126, 317-332.

Foy, C. D., Chaney, R. L. \& White, M. C. (1978). The physiology of metal toxicity in plants. Annual Review of Plant Physiology 29, 511-523.

GuPTA, B. L. \& Hall, T. A. (1979). Quantitative electron probe X-ray microanalysis of electrolyte elements within epithelial tissue compartments. Federation Proceedings 38, 144-153.

HaLL, T. A. (1971). The microprobe assay of chemical elements. In Physical Techniques in Biochemical Research, vol. 1A, pp. 157-175. Edited by G. Oster. New York: Academic Press.

HaUg, A. (1984). Molecular aspects of aluminium toxicity. Critical Reviews of Plant Science 1, 345-373.

Jensen, T. E., BaXter, M., Rachlin, J. W. \& Jani, V. (1982). Uptake of heavy metals by Plectonema boryanum (Cyanophyceae) into cellular components especially polyphosphate bodies: an X-ray energy dispersive study. Environmental Pollution (Series A) 27, 119-127.

Kulaev, I. S. \& Vagabov, M. (1983). Polyphosphate metabolism in microorganisms. Advances in Microbial Physiology 24, 83-158.

Liljesvan, B. \& RoOmans, G. M. (1976). Use of pure carbon specimen holders for analytical electron microscopy of thin sections. Ultramicroscopy 2, 105107.

Morgan, A. J., Davies, T. W. \& Erasmus, D. A. (1975). Analysis of droplets from iso-atomic solutions as a means of calibrating a transmission electron analytical microscope (TEAM). Journal of Microscopy 104, 271-280.

Pedersén, M., Roomans, G. M., ANdrén, M., LIGNELl, A., Lindahl, G., WallströM, K. \&
FORSBERG, $\AA$. (1981). X-ray microanalysis of metals in algae - a contribution to the study of environmental pollution. Scanning Electron Microscopy II, 499 509.

Pettersson, A., Hällbom, L. \& Bergman, B. (1985). Physiological and structural responses of the cyanobacterium Anabaena cylindrica to aluminium. Physiologia plantarum 63, 153-158.

ROOMANS, G. M. (1980a). Localization of divalent cations in phosphate-rich cytoplasmic granules in yeast. Physiologia plantarum 48, 47-50.

Roomans, G. M. (1980b). Quantitative X-ray microanalysis of thin sections. In $X$-ray Microanalysis in Biology, pp. 401-453. Edited by M. A. Hayat. Baltimore: University Park Press.

Roomans, G. M. \& Kuypers, G. A. J. (1980). Background determination in X-ray microanalysis of biological thin sections. Ultramicroscopy 5, 81-83.

Roomans, G. M. \& Sevéus, L. A. (1976). Subcellular localization of diffusible ions in the yeast Saccharomyces cerevisiae: quantitative microprobe analysis of thin freeze-dried sections. Journal of Cell Science 21, 119-127.

Roomans, G. M. \& Sevéus, L. A. (1977). Preparation of thin cryosectioned standards for quantitative microprobe analysis. Journal of Submicroscopic Cytology 9, 31-35.

Roomans, G. M., Wei, X. \& Sevéus, L. (1982). Cryoultramicrotomy as a preparative method for $\mathrm{X}$-ray microanalysis in pathology. Ultrastructural Pathology 3, 65-84.

Russ, J. C. (1974). The direct element ratio model for quantitative analysis of thin sections. In Microprobe Analysis as Applied to Cells and Tissues, pp. 269-276. Edited by T. Hall, P. Echlin \& R. Kaufman. London: Academic Press. 